\title{
Differences and Similarities Between Coronaviruses: A Comparative Review
}

\author{
Maad M. Mijwil ${ }^{1}$, Ayser Shamil Alsaadi² and Karan Aggarwal ${ }^{3}$ \\ ${ }^{1}$ Computer Techniques Engineering Department, Baghdad College of Economic Sciences University, \\ Baghdad, Iraq \\ Email: mr.maad.alnaimiy [AT] baghdadcollege.edu.iq \\ ${ }^{2}$ Ministry of Education, \\ Baghdad, Iraq \\ Email: eng.aysser83 [AT] gmail.com
}

\author{
${ }^{3}$ Electronics and Communication Engineering Department, Maharishi Markandeshwar (Deemed to be University), \\ Mullana, Ambala, India \\ Email: karan.170987 [AT] gmail.com
}

\begin{abstract}
Today, humans fight powerful and active viruses that never take hold and do not know defeat, named coronaviruses. These viruses have start in 2002 and continued to grow and have changed their chains dramatically until now. They are known for having many similar features in common, and there are also structural differences between them. The most important reason that has turned coronaviruses into a pandemic is that this disease is easily transmitted by droplets near infected people, which leads to the spread of this virus faster worldwide. The more details known about coronaviruses that have profoundly affected humanity in the past and present and the diseases they cause, the more benefit in help designing an immune response or preventive vaccine to these viruses in the near future. In this article, coronaviruses, how they have been started and spread, and what differences and similarities are between them will be briefly covered here. The information of this investigation is taken from articles and the world health organization and are reviewed here. The goal is to document this information for future reference.
\end{abstract}

Keywords-Coronavirus, SARS, MERS, COVID-19, Pandemic, China.

\section{INTRODUCTION}

The world may be surprised when the new Coronavirus developed and spread in most countries and regions of the world. Furthermore, world archives are full of pandemics and deadly diseases that wiped out hundreds of millions of people and caused crises that took many years to overcome. The most famous of these pandemics is the Black Plague [1], the Spanish Flu [2], and many other outbreaks that have changed the lives of many societies. Now in 2021, COVID-19 [3] [4] is still easily transmitted and infects many victims, and we do not know what is in store for us in the future. During a pandemic, to reduce the damage that may happen in many areas such as health, social and economic, disease development in the society must be under control. Governments in each country must report ways of transmitting the virus, signs and symptoms of the disease, and the effect of isolating sick and contacts from the public. The rate of spread of the virus can be reduced if society takes significant acts consciously and complies with the rules established to control the epidemic. Therefore, fewer people contract the virus, fewer people get sick, and fewer people need hospitalization, which will lead to a decrease in the number of deaths. For example, the Turkish Ministry of Health (T.C. Sağlık Bakanlığı) has published a complete file on ways to prevent the COVID-19 pandemic. This file contains four pages in Turkish language for Turkish citizens to save their lives from this virus [5]. Also, this platform is designed to learn about the COVID-19 virus and ways to prevent it.

Coronavirus is a family of viruses with one positive polarity encapsulated in RNA that can become a human pathogen with sizes up to $120 \mathrm{~nm}$ [6] [7]. All types of Coronaviruses are of animal sources [8] [9], such as bats or mice. Moreover, it has been observed that SARS-CoV, one of the viruses that cause the pandemic disease, is from civet cats [10] [11], MERS-CoV from camels [12], and COVID-19 may be transmitted by bats and transmitted to humans. Figure 1 shows a type of bat that is expected to be the main reason for the spread of COVID-19 according to an article published on the British BBC news site by Helen Briggs [13]. These viruses begin their period of activity in autumn and winter, causing mild or strong infections in the upper respiratory system of humans, as these viruses can mutate over time and lead to death. The diseases caused by coronaviruses are transmitted through contact with infected people. It is most often spread by breathing. Figure 1 (b) shows the ways of transmission of coronaviruses from bats to humans [14]. 


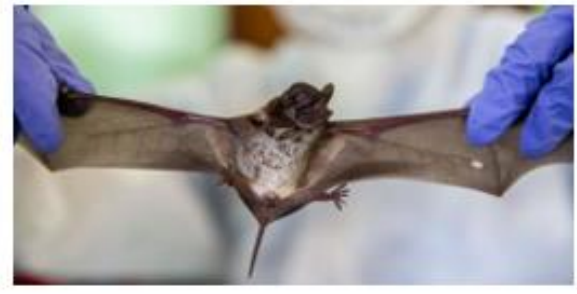

(a)

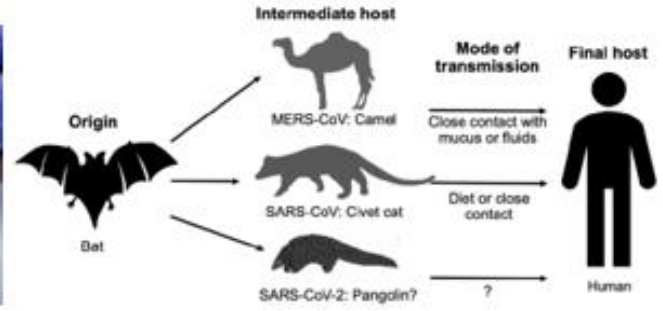

(b)

Figure 1: (a) Report by BBC about the bats. (b) The origins and intermediate hosts of COVID-19, SARS-CoV, and MERS-CoV.

Coronaviruses [15-18] have the characteristic of quick transmission between people if the necessary anticipations are not taken. Various ways of spreading the Coronavirus have been identified. The ways in which these viruses are transmitted are droplet pollution, contact with the person carrying the virus and talking with him/her, coughing, sneezing, breathing in a place where the virus is spreading, as droplets loaded with viruses spread in the air. In addition, the virus is transmitted by somebody inhaling these droplets from close range. The virus can also spread by depositing virus-laden droplets on various surfaces and objects. The person who touches this contaminated surface; may become infected with a virus by blowing the hand into the mouth, nose, or eyes.

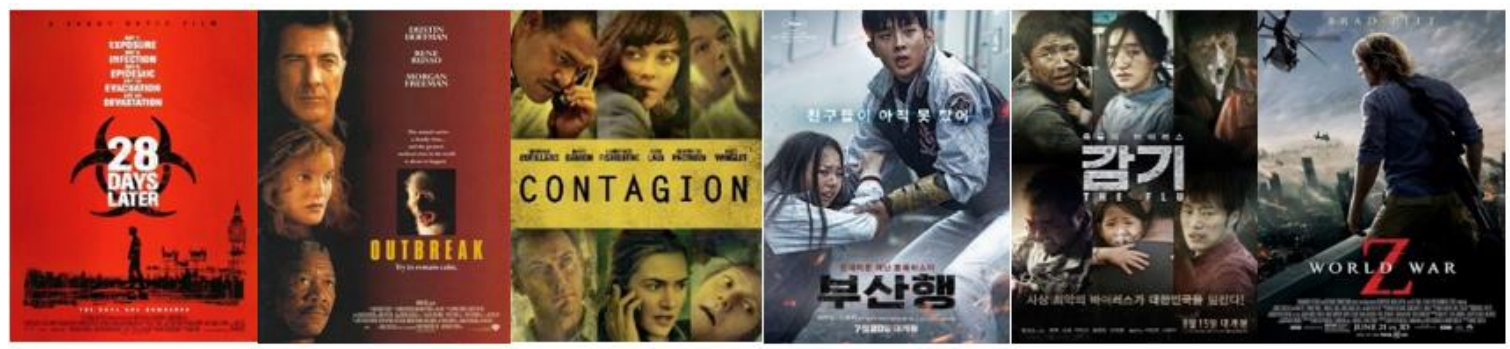

Figure 2: Films covers that predicted the emergence of deadly viruses [downloaded from Google Images]

Before the emergence of the Coronavirus, several films predicted the emergence of deadly viruses that threaten the survival of the human race. The most famous films are a Contagion that has received more attention since the spread of the Coronavirus globally than it received during its release in 2011. However, the events of the film are similar to the emergence of the virus to a noticeable extent, as Its events revolve around a virus that appears in Asia that spreads quickly and causes thousands of deaths amid a government blunder in an attempt to control the mass panic and find a quick cure. Figure 2 presenting the film covers (like Contagion, Train to Busan, 28 Days Later, World War Z, Outbreak and The Flu) that predicted the emergence of deadly viruses.

The primary purpose of this article is to present an overview of how coronaviruses have started and the number of infections and deaths these viruses have achieved and to display the differences and similarities between them. In addition, the ways of virus transmission, the symptoms caused by this virus that appear on the patient, and other information are reviewed. The contribution this article makes is to describe and document sufficient and concise information on coronavirus.

The rest of the article is organized as follows. Part 2 deals with a survey of coronaviruses, how they started, what symptoms they cause, and other information about them. In the part 3, the statistics of the spread of COVID-19 in each nation are presented in terms of the number of cases and deaths and a comparison between coronaviruses. Finally, the conclusions reached in this article are presented in Part 4.

\section{THE CORONAVIRUSES}

In this section, a brief review is presented about coronaviruses:

\subsection{SARS-CoV Pandemic}

Severe acute respiratory syndrome (SARS) [19-21] is the first outbreak of the Coronavirus, which is a severe acute respiratory syndrome disease. It has begun in China in February 2003 and affected twenty-nine countries with nearly 8,096 cases and 744 deaths. The main symptoms of the disease caused by SARS-CoV are high temperature, muscle pain, lethargy, cough, sore throat, and shortness of breath. Figure 3 illustrates the structure of SARS-CoV [22]. Laboratory outcomes of this disease are lymphopenia, thrombocytopenia, and high levels of hydrogen lactate. The viral load of SARS-CoV in specimens from the upper respiratory tract of the victims reached its highest value approximately three days after symptoms developed in those infected. As for specimens obtained from the lower respiratory tract, the viral 
load had its highest value ten days after the onset of symptoms in the infected. That is why it is favoured at that time to obtain specimens from the upper respiratory tract for diagnosis of cases.

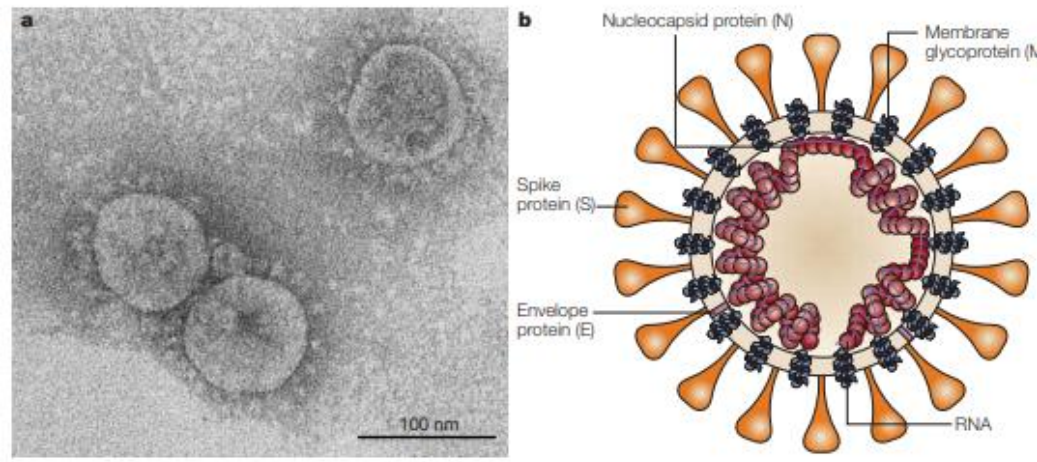

Figure 3: Morphology of the SARS coronavirus. (a) Electron micrograph of the virus. (b) Schematic representation of the virus

At that time, the use of plasma, Hyper immunoglobulin or human monoclonal antibodies of recovered individuals that contain neutral antibodies against the SARS virus is sufficient. Ribavirin and interferon-alpha- $2 b$, which are among the antiviral agents, are tested separately and in integrated in both laboratory and animal studies, and are observed to give more reliable effects. In fact, these studies have not been tested on a sufficient number of people who are infected with this virus, meaning that not enough time is given to discover a way to treat and get rid of the virus. In the author's opinion, if that time is used by the person to follow up on the development of the virus and conduct many studies, COVID-19 would not have been very serious at this time. In addition, the administration of corticosteroids to the affected persons gave satisfactory results. For patients with breathing difficulties, oxygen therapy is utilised first, and then after that, invasive mechanical ventilation is applied when acute respiratory distress syndrome develops. The most critical people for the high death rate from SARS are 65 years and over. This is followed by the age group of 45-64 years. The least affected group is children, as is the case now with COVID-19. Figure 4 presents images in 2003 in China during the SARS pandemic, these images are downloaded from Google. The SARS pandemic is transmitted like COVID-19 between humans and they have the same symptoms, as it is less contagious, in addition to that its transmission is linked to the appearance of symptoms on the patient, unlike COVID-19, and this enabled the chain of transmission to stop. The researcher noted that the "SARS" virus is like other respiratory viruses seasonally, "it appears in the winter and stops in early spring."

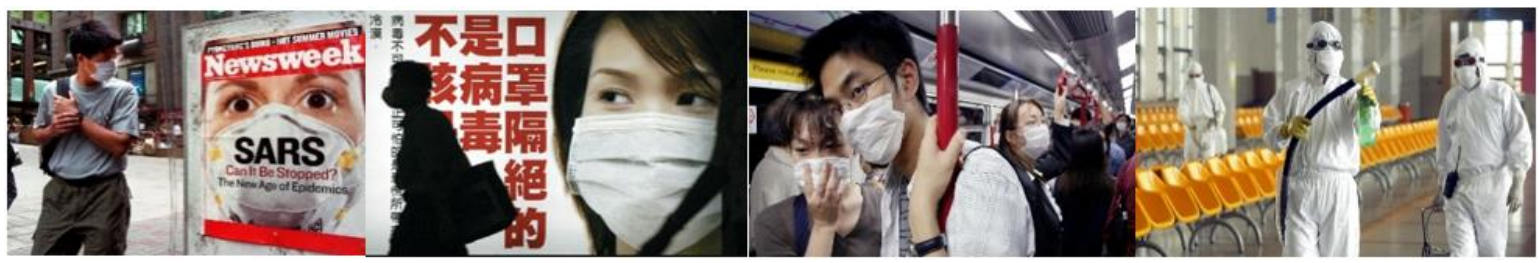

Figure 4: SARS pandemic in China during 2003 [downloaded from Google images]

\subsection{MERS-CoV Pandemic}

Middle East respiratory syndrome (MERS) [23-25] is the first human coronavirus to taxonomically belong to the Cell lineage of the genus Betacoronavirus within the Coronaviridae family. MERS is first found to cause the disease in people in Saudi Arabia in 2012. This type of virus has resulted in nearly 2,500 cases and more than 800 deaths, and there are still sporadic cases. In Middle Eastern countries, MERS is spread to people by an infected camel. MERS is sometimes spread between people who are in close contact with others, such as those who care for or live with someone who is sick. Health workers and family contacts of patients are more likely to get sick. Most of the cases MERS have occurred in Middle Eastern countries like Arabia Saudi, United Arab Emirates, Qatar, Oman, Jordan and Kuwait. On rare occasions, MERS cases have occurred in other countries among people who travelled to the Middle East or their close contacts. In May 2015, the largest cluster of MERS infections outside of the Middle East occurred in South Korea, which has now ended. The main symptom of this disease is high temperature, cough, muscle pain, diarrhoea and vomiting. In addition to these symptoms, serious complications such as pneumonia and kidney failure have been noted. Figure 5 shows the structure of the MERS virus [26], while Figure 6 shows the methods of transmission of this virus from camels to humans and animals [27]. The values of the peak viral load for MERS-CoV in patients peak between 7-10 days after the onset of symptoms in samples from the upper respiratory tract, and on the eleventh day in those from the lower respiratory tract. Dyall et al. (2014) [28] have investigated several antagonist agents with potential therapeutic efficacy. Cyclosporine A, Mycophenolic Acid, Interferon Beta, Homoharringtonine, Cycloheximide, Anisomycin and Emitendine Hydrochloride Hydrate have been found to be the strongest activity in vitro against the Coronavirus [28]. According to 
the report published by the World Health Organization, the age group with the fastest transmission of MERS is 50-59, while the second risk group is 30-39. Mortality rates appear most often at ages 50-59, then 70-79 years old.
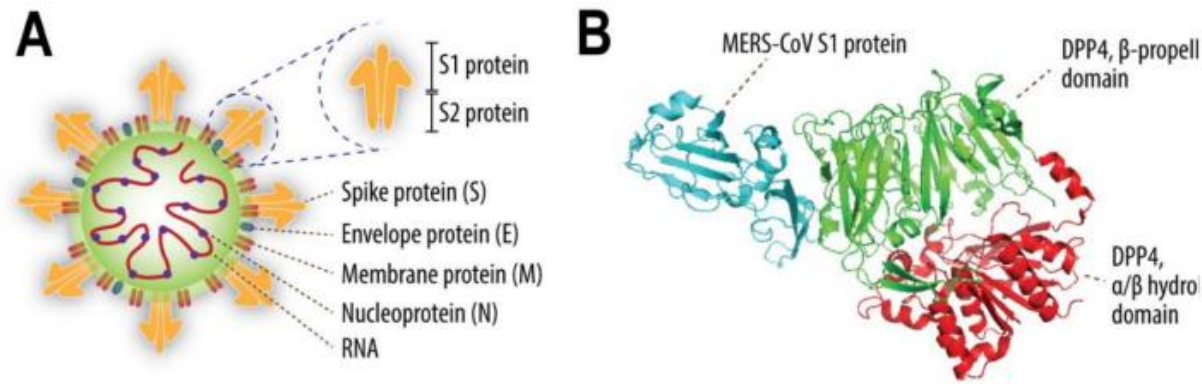

Figure 5: The structural of MERS-CoV), (A); a cartoon representation of MERS-CoV, (B). The S protein consists of MERS

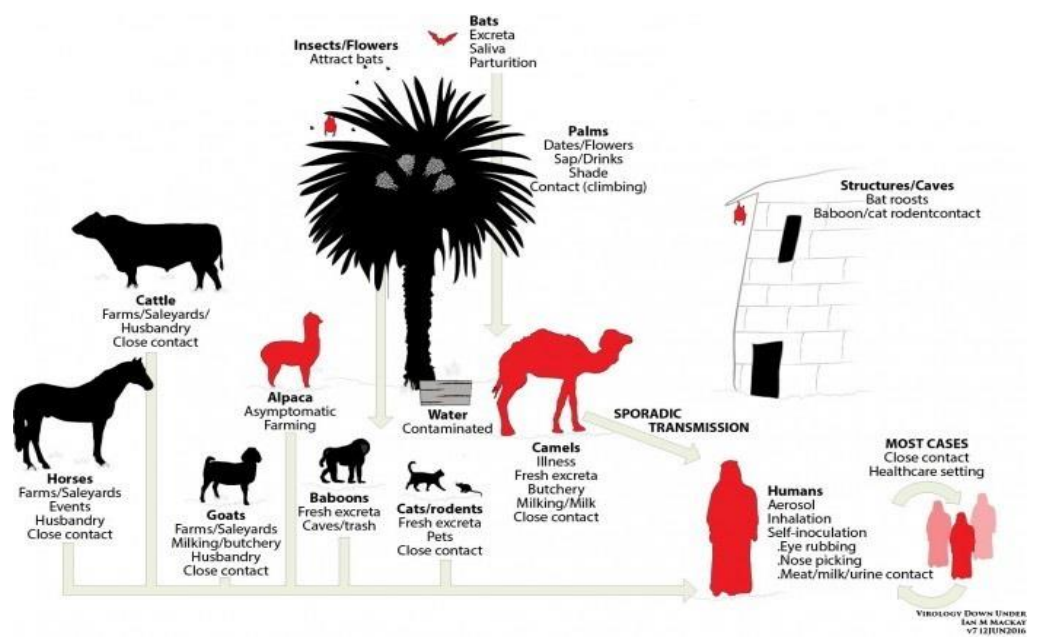

Figure 6: Diagram of the transmission and infection caused by MERS-CoV from camels to humans and animals.

\subsection{COVID-19 Pandemic}

COVID-19 [29-32] has become a pandemic shortly after the first case emerged. This pandemic has greatly affected people's lives, as until May 2021, a large number of victims have been killed, exceeding three million. The earth lives in the time of Covid-19, in which the number of infections and deaths increases day after day, even after the issuance of several vaccinations. However, the situation is still hazardous and not reassuring. Common symptoms of this disease: fever, cough, and shortness of breath (see Figure 8). In addition, pneumonia, acute respiratory failure, multiple organ failure and death have been observed in people with advanced disease. The ideal diagnostic method for identifying COVID-19 is quantitative real-time polymerase chain reaction (qRT-PCR) with a nasopharyngeal swab taken from a victim. In this method, accurate and sensitive results are collected using oligonucleotide probes defined with special fluorescent dyes. However, it has been remarked that chest tomography of patients is essential in determining the percentage of this virus in the lung because it allows diagnosing the disease and planning the diagnostic process. Laboratory outcomes for this virus exhibited decreased lymphocytes and increased C-reactive protein (CRP) and proinflammatory cytokines (such as IL-6, TNF-a, IL-1, IL-8). Moreover, immune cell inflammation has been observed in the infection sites in the lung and lymphocyte infiltration is minimal. These conditions can cause blood clotting and damage to multiple organs.

Figure 7 is a set of images captured in China showing the preventive measures taken by China to reduce the spread of the virus. A method used to treat COVID-19 is plasma therapy. This method involves the use of antibodies against this virus by people who recover and overcome this virus. This method is especially applicable to patients whose health condition is poor and who do not benefit from drug therapy. Children are noted to have less COVID-19 than adults, and clinical attack rates for patients in the 0-19 age group are insignificant. In fact, the effort of the elderly and chronically ill with COVID-19 is, unfortunately, more challenging and affects their quality of life in a significant way. COVID-19 transmission in children is usually from family or school. Children who get the virus in their bodies often get rid of the virus without showing any symptoms. During this period, the child is likely to infect his / her immediate environment with a virus. In addition, the virus burden of children under the age of 5 who overcome COVID-19 may be higher than adults. In such cases, the contagiousness of the child may increase. In New York State-USA, in May 2020, life and death rates for COVID-19 patients are $48 \%$ for the 75 or older age group, $25 \%$ for the $65-74$ age group, $22 \%$ for the $45-64$ age 
group, and 5\% for 44 ages. The first person to discover the existence of the COVID-19 virus is the Chinese ophthalmologist Li Wenliang, who has warned doctors of a fatal disease similar to SARS and more severe. However, the Chinese police asked him to "stop making false comments", and he was controlled to investigate charges of "spreading rumours." After that, he is dead by COVID-19.

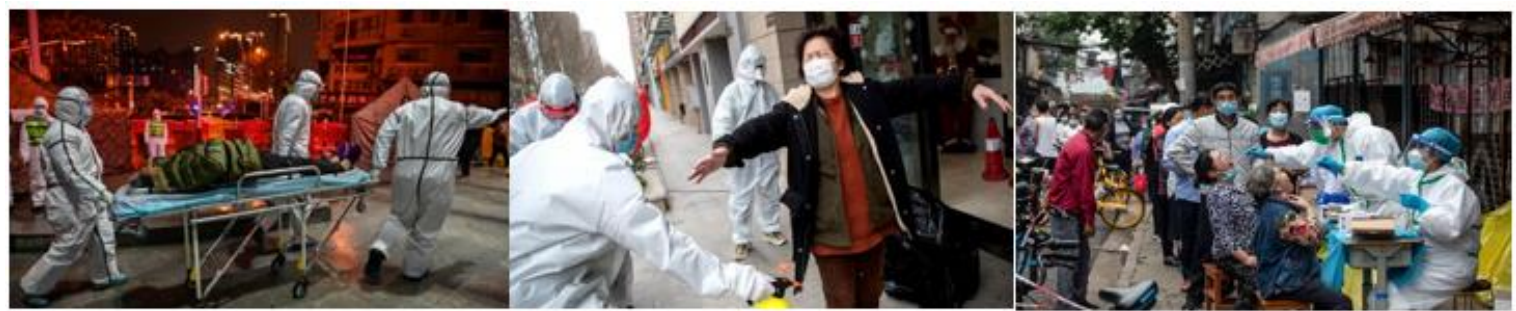

Figure 7: COVID-19 pandemic in China during 2020 [these images downloaded from google images].

Symptomatic transmission is when a person spreads the virus while showing signs and symptoms of the disease after being infected with the virus. For example, a person with a cough problem, which is one of the common symptoms of COVID-19, causes virus-laden droplets to scatter into the air while coughing. Symptomatic transmission occurs when a healthy person breathes the scattered droplets ingesting the virus. Research on the ways of coronavirus spread continues worldwide. According to the latest information obtained, a person with COVID-19; The first 3 days after the onset of symptoms is when the contagion is at its highest. Contagiousness decreases in the later stages of the disease. Coronavirus incubation period; It refers to the time elapsed after the virus is ingested until symptoms begin to appear. The coronavirus incubation period is on average 5-6 days. In other words, a person begins to show signs of illness about 5 days after ingesting the virus. However, in some people, the corona incubation period may take up to 14 days. Therefore, contact persons are isolated for 14 days, which is the longest possible incubation period. Some people can spread the virus around during the corona incubation period. In this case, which is also called pre-symptom transmission, the person can transmit the virus to healthy people before showing any symptoms. In studies on the spread of the virus, it has been reported that some people were tested positive for coronavirus 1-3 days before they started showing symptoms. Based on this data, it has been observed that there is a possibility of spreading the virus before people enter the symptomatic stage. Incubation period transmission; It can take place through inhalation of the virus or contact with contaminated surfaces. It is wrong for people to think that they will not transmit the virus to their immediate environment because they do not show symptoms of COVID-19. Asymptomatic cases are those who do not show any symptoms despite carrying the virus in their body. Identifying asymptomatic people in the community is very difficult, as no symptoms are seen in the individuals in this group. Various studies have been conducted on virus spread from asymptomatic people to healthy people. However, these studies do not find a clear answer to the extent to which the transmission from asymptomatic persons is effective on virus spread. Some experts consider asymptomatic carriers to be a key factor in the expansion of COVID-19's domain. It should not be forgotten that individuals who appear completely healthy can be asymptomatic carriers. Coronavirus precautions should be strictly followed in contact with any person showing or not showing symptoms.

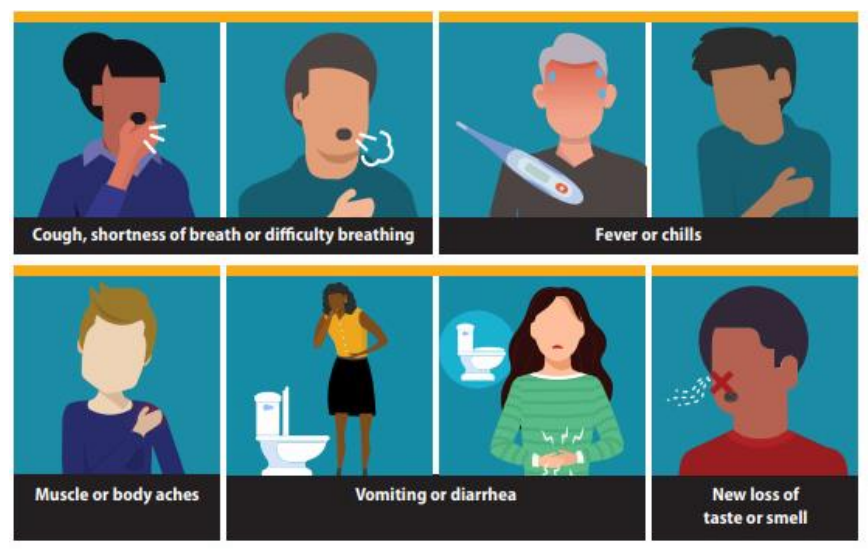

Figure 8: COVID-19 Symptoms [33]

\section{COVID-19 STATISTICS WORLDWIDE}

Documentation is one of the necessary methods of saving and arranging information and events that can be a source in the future to benefit from them. After the spread of the COVID-19 pandemic and its control over the lives of the 
world's population, several sites and platforms have appeared that publish statistics that including the number of cases, the number of deaths, and the number of people who have recovered from this disease. These statistics require a documentation process in one article. In this section, the authors decide to document the statistics of COVID-19 disease and save them in this article from the first infection in Wuhan city until April 2021. In this section, the latest results published on the WHO website about the spread of the COVID-19 in all nations are reviewed. Table 1 shows the difference between coronaviruses in terms of first report, status, number of infections and treatment. Table 2 exhibits COVID-19 report as of 15th April 2021. In a study conducted by Mbagwu et al. from Nigeria [34], they are able to collect infection and death statistics in all nations of the world from the beginning of the outbreak until March 2020.

Table 1: The difference between coronaviruses until April 2021

\begin{tabular}{|c|c|c|c|}
\hline & MERS-CoV & SARS-CoV & COVID-19 or SARS-CoV 2 \\
\hline First reported & Saudi Arabia 2012 & China 2002 & China 2019 \\
\hline Current Status & Active & No reports since 2004 & Active \\
\hline Infections & $2521+$ & 8098 & $137,000,000+$ \\
\hline Treatments & None & None & None \\
\hline
\end{tabular}

Table 2: COVID-19 Report as of $15^{\text {th }}$ April 2021 [35]

\begin{tabular}{|c|c|c|c|}
\hline Nations & $\begin{array}{c}\text { Cases - Cumulative } \\
\text { Total }\end{array}$ & $\begin{array}{c}\text { Deaths - Cumulative } \\
\text { Total }\end{array}$ & $\begin{array}{c}\text { Cases Reported } \\
\text { in Last } 7 \text { Days }\end{array}$ \\
\hline All Nations & 137866311 & 2965707 & 5043855 \\
\hline United States of America & 31029700 & 558238 & 488700 \\
\hline India & 14074564 & 173123 & 1145990 \\
\hline Brazil & 13599994 & 358425 & 499414 \\
\hline France & 5069999 & 99145 & 231645 \\
\hline Russian Federation & 4675153 & 104398 & 60319 \\
\hline United Kingdom & 4378309 & 127161 & 16416 \\
\hline Turkey & 4025557 & 34734 & 391632 \\
\hline Italy & 3809193 & 115557 & 108800 \\
\hline Spain & 3387022 & 76756 & 51509 \\
\hline Germany & 3073442 & 79381 & 142590 \\
\hline Poland & 2642242 & 60612 & 142735 \\
\hline Argentina & 2579000 & 58174 & 150971 \\
\hline Colombia & 2569314 & 66482 & 101078 \\
\hline Mexico & 2286133 & 210294 & 29753 \\
\hline Iran & 2143794 & 65359 & 159446 \\
\hline Ukraine & 1903765 & 38658 & 99767 \\
\hline Peru & 1659707 & 55489 & 61114 \\
\hline Czechia & 1593847 & 28229 & 25999 \\
\hline Indonesia & 1583182 & 42906 & 35806 \\
\hline South Africa & 1561559 & 53498 & 7950 \\
\hline Netherlands & 1369411 & 16848 & 50256 \\
\hline Chile & 1094267 & 24548 & 51245 \\
\hline Canada & 1078562 & 23392 & 57669 \\
\hline Romania & 1016449 & 25605 & 27825 \\
\hline Iraq & 949050 & 14836 & 53428 \\
\hline Belgium & 935316 & 23603 & 19638 \\
\hline Philippines & 892880 & 15447 & 73730 \\
\hline Sweden & 885385 & 13720 & 43596 \\
\hline Israel & 836504 & 6312 & 1119 \\
\hline Portugal & 828857 & 16931 & 3826 \\
\hline Hungary & 736982 & 24521 & 38492 \\
\hline Pakistan & 734423 & 15754 & 34235 \\
\hline
\end{tabular}




\begin{tabular}{|c|c|c|c|}
\hline Bangladesh & 703170 & 9987 & 43892 \\
\hline Jordan & 676175 & 7987 & 25494 \\
\hline Serbia & 651899 & 5846 & 22511 \\
\hline Switzerland & 625103 & 9790 & 12069 \\
\hline Austria & 580601 & 9530 & 17839 \\
\hline Japan & 516121 & 9500 & 23246 \\
\hline Morocco & 503664 & 8920 & 3976 \\
\hline Lebanon & 502299 & 6778 & 16381 \\
\hline United Arab Emirates & 489495 & 1541 & 13476 \\
\hline Saudi Arabia & 401157 & 6781 & 6205 \\
\hline Bulgaria & 380576 & 14871 & 16157 \\
\hline Slovakia & 373950 & 10877 & 5480 \\
\hline Malaysia & 365829 & 1353 & 11361 \\
\hline Panama & 359121 & 6173 & 2208 \\
\hline Ecuador & 350539 & 17400 & 10935 \\
\hline Belarus & 338801 & 2383 & 8265 \\
\hline Kazakhstan & 330319 & 3963 & 15217 \\
\hline Greece & 304184 & 9135 & 19169 \\
\hline $\begin{array}{l}\text { occupied Palestinian } \\
\text { territory, including east } \\
\text { Jerusalem }\end{array}$ & 303470 & 3190 & 15635 \\
\hline Croatia & 300900 & 6442 & 15135 \\
\hline Georgia & 292244 & 3908 & 5838 \\
\hline Azerbaijan & 291894 & 4009 & 15430 \\
\hline Bolivia & 284183 & 12496 & 7293 \\
\hline Nepal & 281564 & 3061 & 2796 \\
\hline Tunisia & 276727 & 9480 & 11733 \\
\hline Dominican Republic & 259260 & 3402 & 4323 \\
\hline Kuwait & 251675 & 1423 & 10206 \\
\hline Republic of Moldova & 243365 & 5466 & 5647 \\
\hline Ireland & 242105 & 4812 & 2780 \\
\hline Paraguay & 240141 & 4978 & 15405 \\
\hline Denmark & 239532 & 2447 & 4601 \\
\hline Ethiopia & 234405 & 3254 & 12861 \\
\hline Lithuania & 230462 & 3730 & 7335 \\
\hline Slovenia & 229076 & 4416 & 7184 \\
\hline Costa Rica & 225343 & 3044 & 5497 \\
\hline Egypt & 212961 & 12570 & 5668 \\
\hline Armenia & 206142 & 3817 & 6013 \\
\hline Guatemala & 205322 & 7057 & 6948 \\
\hline Honduras & 196704 & 4873 & 4291 \\
\hline Qatar & 192963 & 348 & 6762 \\
\hline Bosnia and Herzegovina & 186372 & 7642 & 7124 \\
\hline Venezuela & 176972 & 1815 & 7898 \\
\hline Oman & 175633 & 1807 & 8948 \\
\hline Libya & 170045 & 2834 & 4758 \\
\hline Nigeria & 163911 & 2061 & 413 \\
\hline Bahrain & 159964 & 569 & 8033 \\
\hline
\end{tabular}




\begin{tabular}{|c|c|c|c|}
\hline Uruguay & 149430 & 1595 & 26367 \\
\hline Kenya & 148128 & 2420 & 6763 \\
\hline North Macedonia & 144111 & 4322 & 6383 \\
\hline Myanmar & 142610 & 3206 & 61 \\
\hline Albania & 128959 & 2331 & 1767 \\
\hline Algeria & 118975 & 3141 & 971 \\
\hline Puerto Rico & 117366 & 2174 & 7133 \\
\hline Estonia & 116200 & 1064 & 3779 \\
\hline Republic of Korea & 112117 & 1788 & 4519 \\
\hline Latvia & 109088 & 2019 & 3912 \\
\hline Norway & 105007 & 706 & 4860 \\
\hline China & 103185 & 4856 & 182 \\
\hline Kosovo & 99493 & 2012 & 4195 \\
\hline Sri Lanka & 95737 & 604 & 1744 \\
\hline Montenegro & 94856 & 1397 & 1055 \\
\hline Ghana & 91477 & 763 & 468 \\
\hline Kyrgyzstan & 91144 & 1540 & 1484 \\
\hline Zambia & 90389 & 1229 & 1003 \\
\hline Cuba & 89404 & 487 & 6803 \\
\hline Uzbekistan & 85730 & 634 & 1408 \\
\hline Finland & 82964 & 881 & 2548 \\
\hline Mozambique & 68927 & 794 & 496 \\
\hline El Salvador & 66816 & 2060 & 1325 \\
\hline Luxembourg & 64334 & 784 & 1541 \\
\hline Cameroon & 61731 & 919 & 4394 \\
\hline Singapore & 60719 & 30 & 165 \\
\hline Afghanistan & 57534 & 2533 & 591 \\
\hline Cyprus & 53254 & 277 & 3888 \\
\hline Namibia & 46051 & 592 & 1012 \\
\hline Côte d'Ivoire & 45265 & 269 & 385 \\
\hline Botswana & 43444 & 663 & 1734 \\
\hline Jamaica & 43054 & 692 & 1654 \\
\hline Uganda & 41237 & 338 & 191 \\
\hline Senegal & 39560 & 1084 & 396 \\
\hline Thailand & 37453 & 97 & 7143 \\
\hline Zimbabwe & 37369 & 1548 & 385 \\
\hline Malawi & 33891 & 1134 & 173 \\
\hline Sudan & 32932 & 2194 & 288 \\
\hline Malta & 29778 & 403 & 370 \\
\hline Australia & 29451 & 910 & 72 \\
\hline Madagascar & 29348 & 520 & 3221 \\
\hline $\begin{array}{l}\text { Democratic Republic } \\
\text { of the Congo }\end{array}$ & 28714 & 745 & 304 \\
\hline Maldives & 25844 & 67 & 653 \\
\hline Angola & 23841 & 557 & 831 \\
\hline Rwanda & 23672 & 317 & 631 \\
\hline Guinea & 21106 & 136 & 552 \\
\hline Gabon & 20971 & 129 & 706 \\
\hline
\end{tabular}




\begin{tabular}{|c|c|c|c|}
\hline Syrian Arab Republic & 20555 & 1402 & 794 \\
\hline Mayotte & 19757 & 168 & 267 \\
\hline Cabo Verde & 19525 & 188 & 1311 \\
\hline French Polynesia & 18680 & 141 & 37 \\
\hline Réunion & 18425 & 135 & 917 \\
\hline Eswatini & 18407 & 670 & 1042 \\
\hline Mauritania & 18066 & 452 & 111 \\
\hline Mongolia & 17823 & 29 & 5597 \\
\hline French Guiana & 17806 & 95 & 488 \\
\hline Tajikistan & 13714 & 91 & 0 \\
\hline Burkina Faso & 13050 & 154 & 177 \\
\hline Haiti & 12857 & 252 & 54 \\
\hline Somalia & 12837 & 656 & 859 \\
\hline Andorra & 12641 & 121 & 278 \\
\hline Belize & 12513 & 318 & 36 \\
\hline Mali & 12467 & 419 & 1626 \\
\hline Guadeloupe & 12304 & 189 & 414 \\
\hline Togo & 12214 & 117 & 713 \\
\hline Curaçao & 11430 & 74 & 1245 \\
\hline Guyana & 11277 & 258 & 640 \\
\hline Lesotho & 10709 & 315 & 2 \\
\hline South Sudan & 10403 & 114 & 106 \\
\hline Djibouti & 10202 & 106 & 896 \\
\hline Aruba & 10122 & 92 & 362 \\
\hline Congo & 10084 & 137 & 0 \\
\hline Bahamas & 9505 & 190 & 209 \\
\hline Suriname & 9363 & 184 & 179 \\
\hline Papua New Guinea & 9188 & 82 & 1349 \\
\hline Martinique & 8887 & 59 & 724 \\
\hline Trinidad and Tobago & 8511 & 146 & 297 \\
\hline Guam & 7640 & 136 & 22 \\
\hline Benin & 7611 & 96 & 96 \\
\hline Equatorial Guinea & 7259 & 106 & 200 \\
\hline Iceland & 6275 & 29 & 24 \\
\hline Gambia & 5682 & 170 & 118 \\
\hline Yemen & 5586 & 1084 & 535 \\
\hline $\begin{array}{c}\text { Central African } \\
\text { Republic }\end{array}$ & 5465 & 74 & 63 \\
\hline Nicaragua & 5407 & 180 & 41 \\
\hline Niger & 5113 & 190 & 61 \\
\hline San Marino & 5004 & 86 & 100 \\
\hline Cambodia & 4874 & 35 & 1846 \\
\hline Chad & 4662 & 167 & 56 \\
\hline Seychelles & 4633 & 25 & 266 \\
\hline Saint Lucia & 4355 & 64 & 51 \\
\hline Gibraltar & 4277 & 94 & 2 \\
\hline Sierra Leone & 4013 & 79 & 20 \\
\hline Comoros & 3873 & 146 & 45 \\
\hline
\end{tabular}




\begin{tabular}{|c|c|c|c|}
\hline Barbados & 3740 & 44 & 49 \\
\hline Guinea-Bissau & 3694 & 66 & 31 \\
\hline Eritrea & 3479 & 10 & 105 \\
\hline Burundi & 3424 & 6 & 397 \\
\hline Jersey & 3232 & 69 & 2 \\
\hline $\begin{array}{l}\text { United States } \\
\text { Virgin Islands }\end{array}$ & 3005 & 26 & 60 \\
\hline Liechtenstein & 2865 & 54 & 57 \\
\hline Viet Nam & 2737 & 35 & 78 \\
\hline Monaco & 2384 & 31 & 32 \\
\hline $\begin{array}{c}\text { Turks and } \\
\text { Caicos Islands }\end{array}$ & 2360 & 17 & 16 \\
\hline $\begin{array}{c}\text { Sao Tome } \\
\text { and Principe }\end{array}$ & 2268 & 35 & 13 \\
\hline New Zealand & 2235 & 26 & 36 \\
\hline Sint Maarten & 2196 & 27 & 32 \\
\hline Liberia & 2071 & 85 & 5 \\
\hline Bermuda & 1935 & 16 & 438 \\
\hline $\begin{array}{c}\text { Saint Vincent } \\
\text { and the Grenadines }\end{array}$ & 1806 & 10 & 40 \\
\hline Saint Martin & 1703 & 13 & 16 \\
\hline Isle of Man & 1575 & 29 & 3 \\
\hline Bonaire & 1502 & 14 & 50 \\
\hline Antigua and Barbuda & 1201 & 31 & 28 \\
\hline Mauritius & 1198 & 15 & 86 \\
\hline Timor-Leste & 1103 & 2 & 268 \\
\hline Bhutan & 929 & 1 & 29 \\
\hline Saint Barthélemy & 928 & 1 & 18 \\
\hline Guernsey & 821 & 14 & 0 \\
\hline Other & 745 & 13 & 0 \\
\hline Faroe Islands & 662 & 1 & 1 \\
\hline Cayman Islands & 523 & 2 & 11 \\
\hline $\begin{array}{l}\text { United Republic } \\
\text { of Tanzania }\end{array}$ & 509 & 21 & 0 \\
\hline Wallis and Futuna & 446 & 5 & 14 \\
\hline Brunei Darussalam & 221 & 3 & 6 \\
\hline British Virgin Islands & 178 & 1 & 0 \\
\hline Dominica & 165 & 0 & 0 \\
\hline $\begin{array}{l}\text { Northern Mariana } \\
\text { Islands }\end{array}$ & 161 & 2 & 1 \\
\hline Grenada & 158 & 1 & 2 \\
\hline New Caledonia & 121 & 0 & 0 \\
\hline Fiji & 68 & 2 & 1 \\
\hline $\begin{array}{l}\text { Falkland Islands } \\
\text { (Malvinas) }\end{array}$ & 62 & 0 & 10 \\
\hline $\begin{array}{c}\text { Lao People's } \\
\text { Democratic Republic }\end{array}$ & 53 & 0 & 4 \\
\hline Saint Kitts and Nevis & 44 & 0 & 0 \\
\hline Greenland & 31 & 0 & 0 \\
\hline
\end{tabular}




\begin{tabular}{|c|c|c|c|}
\hline Anguilla & 29 & 0 & 4 \\
\hline Holy See & 26 & 0 & 0 \\
\hline $\begin{array}{c}\text { Saint Pierre } \\
\text { and Miquelon }\end{array}$ & 25 & 0 & 1 \\
\hline Montserrat & 20 & 1 & 0 \\
\hline Sint Eustatius & 20 & 0 & 0 \\
\hline Solomon Islands & 19 & 0 & 0 \\
\hline Saba & 6 & 0 & 0 \\
\hline Marshall Islands & 4 & 0 & 0 \\
\hline Samoa & 4 & 0 & 0 \\
\hline Vanuatu & 3 & 0 & 0 \\
\hline American Samoa & 0 & 0 & 0 \\
\hline Cook Islands & 0 & 0 & 0 \\
\hline $\begin{array}{l}\text { Democratic People's } \\
\text { Republic of Korea }\end{array}$ & 0 & 0 & 0 \\
\hline Kiribati & 0 & 0 & 0 \\
\hline Micronesia & 0 & 0 & 0 \\
\hline Nauru & 0 & 0 & 0 \\
\hline Niue & 0 & 0 & 0 \\
\hline Palau & 0 & 0 & 0 \\
\hline Pitcairn Islands & 0 & 0 & 0 \\
\hline Tokelau & 0 & 0 & 0 \\
\hline Tonga & 0 & 0 & 0 \\
\hline Turkmenistan & 0 & 0 & 0 \\
\hline Tuvalu & 0 & 0 & 0 \\
\hline
\end{tabular}

\section{CONCLUSIONS}

The summary of this article is that more than $80 \%$ of people who have contracted the COVID-19 pandemic have recovered. This is an excellent indicator that may help in growing the vaccine. This article explains that coronavirus is in continuous development, especially after the emergence of the Indian COVID-19, which has swept India and killed many Indian citizens. It is necessary to comply with the recommendations determined by the experts in reducing the rate of corona transmission in the society. Except for mandatory situations, it would be beneficial for the person to stay away from crowded environments. It is recommended that people do not contact other people unless they have to. It should be kept in mind that the other party may also be carrying the coronavirus in cases of forced contact. Corona contamination distance has been determined by experts to be approximately 1.5-2 meters. Therefore, in cases where it is necessary to contact other people, it will be beneficial to have a gap of at least 2 meters between people. In addition, wearing masks on both sides can reduce virus spread by preventing people from spilling droplets into the air while speaking. In areas outside the home, everyone aged 2 years and over is recommended to wear a mask.

\section{REFERENCES}

[1] Kathryn A., Glatter, and Finkelman P., "History of the Plague: An Ancient Pandemic for the Age of COVID-19," The American Journal of Medicine, vol.134, no.2, pp:176-181, February 2021. https://doi.org/10.1016/j.amjmed.2020.08.019

[2] Tsoucalas G., Kousoulis A., and Sgantzos M., "The 1918 Spanish Flu Pandemic, the Origins of the H1N1-virus Strain, a Glance in History," European Journal of Clinical and Biomedical Sciences, vol.2, no.4, pp:23-28, January 2016, https://doi.org/10.11648/j.ejcbs.20160204.11

[3] Mijwil, M. M., "Implementation of Machine Learning Techniques for the Classification of Lung X-Ray Images Used to Detect COVID-19 in Humans," Iraqi Journal of Science, vol.62, no.6., pp: 2099-2109, July 2021. https://doi.org/10.24996/ijs.2021.62.6.35.

[4] Umakanthan S., Sahu P., Ranade A. V., Bukelo M. M., Rao J. S., Abrahao-Machado L. F., Dahal S., Kumar H., Dhananjaya KV., "Origin, transmission, diagnosis and management of coronavirus disease 2019 (COVID-19)," Postgraduate Medical Journal, vol.96, pp:753-785, July 2020. https://doi.org/10.1136/postgradmedj-2020-138234 
[5] Docment by Turkish Ministry of Health, “\#COVID-19 Turkish Ministry of Health: Isolation Methods for Medical Personnel-Turkish (Turkish language), pp:1-4, March 2020, Available link: https://data2.unhcr.org/en/documents/details/74803

[6] Wang M., Zhao R., Gao L., Gao X., Wang D., and Cao J., "SARS-CoV-2: Structure, Biology, and Structure-Based Therapeutics Development," Frontiers in Cellular and Infection Microbiology, vol.10, pp:724-740, November 2020. https://doi.org/10.3389/fcimb.2020.587269

[7] Britannica, The Editors of Encyclopaedia. "Coronavirus". Encyclopedia Britannica, 23 Feb. 2021, https://www.britannica.com/science/coronavirus-virus-group.

[8] Mallapaty S., "Animal Source of the Coronavirus Continues to Elude Scientists," nature, May 2020, https://www.nature.com/articles/d41586-020-01449-8

[9] Christine K. Johnson, Why We Don't Know the Animal Origins of the Coronavirus, Scientific American, June 2021. https://www.scientificamerican.com/article/finding-conclusive-animal-origins-of-the-coronavirus-will-taketimel

[10] Hosie M. J., Hofmann-Lehmann R., Hartmann K., et al., "Anthropogenic Infection of Cats during the 2020 COVID19 Pandemic," Viruses- MDPI, vol.13, no.158, pp:1-13, January 2021. https://doi.org/10.3390/v13020185

[11] Tu C., Crameri G., Kong X., et al., “Antibodies to SARS Coronavirus in Civets," Emerging Infectious Diseases, vol.10, no.12, pp:2244-2248, December 2004. https://doi.org/10.3201/eid1012.040520

[12] Hemida M. G., Chu D. K. W., Poon L. L. M., et al., "MERS Coronavirus in Dromedary Camel Herd, Saudi Arabia," Emerging Infectious Diseases, vol. 20, no.7, pp: 1231-1234, July 2014. http://dx.doi.org/10.3201/eid2007.140571

[13] Briggs H., "Coronavirus: Bat Scientists Find New Evidence," BBC News- science, February 2021, https://www.bbc.com/news/science-environment-55998157

[14] Yi Y, Lagniton P. N. P., Ye S., Li E., and Xu R., "COVID-19: hat has been learned and to be learned about the novel coronavirus disease," International Journal of Biological Sciences, vol. 16, no.10, pp:1753-1766, March 2020. https://doi.org/10.7150/ijbs.45134

[15]Zhang X., Huang H., Zhuang D., Nasser M. I., Yang M., Zhu P., and Zhao M., "Biological, clinical and epidemiological features of COVID-19, SARS and MERS and AutoDock simulation of ACE2," Infectious Diseases of Poverty, vol.9, July 2020. https://doi.org/10.1186/s40249-020-00691-6

[16] Shereen M. A., Khan S., Kazm A., Bashir N., and Siddique R., "COVID-19 infection: Origin, transmission, and characteristics of human coronaviruses," Journal of Advanced Research, vol.24, pp:91-98, July 2020. https://doi.org/10.1016/j.jare.2020.03.005

[17] Wang D., Hu B., Hu C., Zhu F., et al., "Clinical Characteristics of 138 Hospitalized Patients With 2019 Novel Coronavirus-Infected Pneumonia inWuhan, China,” JAMA, vol.323, no.11, pp:1061-1069, February 2020. https://doi.org/10.1001/jama.2020.1585

[18] Yin Y. and Wunderink R. G., "MERS, SARS and Other Coronaviruses as Causes of Pneumonia," Respirology, vol.23, pp:130-137, 2018. https://doi.org/10.1111/resp.13196

[19] Christian M. D., Poutanen S. M., Loutfy M. R., Muller M. P., and Low D. E., "Severe Acute Respiratory Syndrome," Clinical Infectious Diseases, vol.38, no.10, pp: 1420-1427, May 2004. https://doi.org/10.1086/420743

[20] Cheng V. C. C., Lau S. K. P., Woo P. C. Y., and Yuen K. Y., "Severe Acute Respiratory Syndrome Coronavirus as an Agent of Emerging and Reemerging Infection," American Society for Microbiology, vol. 20, no.4, pp:660-694, October 2007. https://doi.org/10.1128/CMR.00023-07

[21] Chan K. S., Lai S. L., Chu C. M., et al., "Treatment of severe acute respiratory syndrome with lopinavir/ritonavir: a multicentre retrospective matched cohort study," Hong Kong Medical Journal, vol.9, no.6, pp: 399-406, December 2003.

[22] Stadler K., Masignani V., Eickmann M., Becke S., Abrignani S., Klenk H., and Rappuoli R., "SARS — Beginning to Understand a New Virus," Nature Reviews Microbiology, vol.1, pp: 200-218, December 2003. https://doi.org/10.1038/nrmicro775

[23] Nah K., Otsuk S., Chowell G., and Nishiura H., "Predicting the international spread of Middle East respiratory syndrome (MERS)," BMC Infectious Diseases, vol.16, no.356, pp:1-9, 2016. https://doi.org/10.1186/s12879-016$\underline{1675-\mathrm{Z}}$

[24] Maltezou H. C., and Tsiodras S., "Middle East respiratory syndrome coronavirus: Implications for health care facilities," American Journal of Infection Control, vol.42, pp:1261-1265, 2014. http://dx.doi.org/10.1016/j.ajic.2014.06.019

[25] Amer H., Alqahtani A. S., Alaklobi F., Altayeb J., and Ziad A. Memish Z. A., "Healthcare worker exposure to Middle East respiratory syndrome coronavirus (MERS-CoV): Revision of screening strategies urgently needed," International Journal of Infectious Diseases, vol.71, pp:113-116, 2018. https://doi.org/10.1016/j.ijid.2018.04.001

[26] Widagdo W., Ayudhya S. S. N., Hundie G. B., and Haagmans B. L., "Host Determinants of MERS-CoV Transmission and Pathogenesis," Viruses, vol.11, no.280, pp:1-14, 2019. https://doi.org/10.3390/v11030280

[27] Mackay I. M., Edited by: Diamond M., Duong A., "Camels, Cattle and Coronavirus: the Middle East Respiratory Syndrome Coronavirus Hunt must Continue," November 2015. Available: https://infectioncontrol.tips/2015/11/23/1004/ 
[28] Dyall J., Coleman C. M., Hart B. J., Venkataraman T., et al. , "Repurposing of clinically developed drugs for treatment of Middle East respiratory syndrome coronavirus infection," Antimicrob Agents Chemother, vol. 58, no.8, pp: 4885-4893, August 2014. https://doi.org/10.1128/AAC.03036-14.

[29] Di Gennaro F., Pizzol D., Marotta C., Antunes M., Racalbuto V., Veronese N., and Smith L., "Coronavirus Diseases (COVID-19) Current Status and Future Perspectives: A Narrative Review," International Journal of Environmental Research and Public Health, vol.17, no.2690, pp:1-11, April 2020. https://doi.org/10.3390/ijerph17082690

[30] Pokhrel S., and Chhetri R., "A Literature Review on Impact of COVID-19 Pandemic on Teaching and Learning," Higher Education for the Future, vol.8, no.1, pp:133-141, 2021. https://doi.org/10.1177/2347631120983481

[31] Clemente-Suárez V. J., Navarro-Jiménez E., Jimenez M., Hormeño-Holgado A., et al., "Impact of COVID-19 Pandemic in Public Mental Health: An Extensive Narrative Review," Sustainability, vol.13, no. 3221, pp: 1-21, March 2021. https://doi.org/10.3390/su13063221

[32] Rauf A., Abu-Izneid T., Olatunde A., Khalil A. A., Alhumaydhi F. A., et al., "COVID-19 Pandemic: Epidemiology, Etiology, Conventional and Non-Conventional Therapies," International Journal of Environmental Research and Public Health, vol.17, no. 8155, pp:1-32, November 2020. https://doi.org/10.3390/ijerph17218155

[33] Symptoms of COVID-19, February 2021, https://www.cdc.gov/coronavirus/2019-ncov/symptomstesting/symptoms.html

[34] Mbagwu J. C., Blessing O., Anyiam I. V., Omeje F. I., "A Review: Global Pattern of Distribution of Novel Corona Virus (COVID-19)," International Journal of Research and Innovation in Applied Science (IJRIAS), vol. V, no. IV, pp:89-95, April 2020.

[35] World Health Organization website, "WHO Coronavirus (COVID-19) Dashboard-2021", https://covid19.who.int/table 